\title{
EDUKASI PROTOKOL KESEHATAN NEW NORMAL DAN PENGENALAN DUNIA BISNIS DI TENGAH PANDEMI COVID-19 MELALUI MEDIA SOSIAL
}

\author{
EDUCATION OF NEW NORMAL HEALTH PROTOCOLS AND \\ INTRODUCTION TO BUSINESS WORLD DURING THE COVID-19 \\ PANDEMIC THROUGH SOCIAL MEDIA.
}

\author{
${ }_{1}$ Calvina Izumi Atmajanti, Gavrial Caesarissa Richtiara, Kinanti Khairunnisa I.S, \\ Dina Az-Zahra, Nadya Aliyya Sophia,Poppy Ayu Rahmawati \\ ${ }^{1}$ Psikologi, Fakultas Psikologi, Universitas Airlangga, Mahasiswa Kuliah Kerja Nyata \\ BBM UNAIR 62 Lembaga Pengabdian Masyarakat, Universitas Airlangga Kampus C \\ UNAIR, Jl. Mulyorejo, Surabaya Jawa Timur, Indonesia, 60115 \\ calvina.izumi.atmajanti-2017@psikologi.unair.ac.id
}

\begin{abstract}
In the midst of the emergency situation that must be experienced by Indonesia, namely the pandemic caused by the COVID-19 virus caused a change in the system in the implementation of the Real Work Lecture. Previously, real work lectures that could be carried out in various regions with a variety of cross-regional students, had to undergo changes, namely the implementation of real work lectures according to the domicile of the student. Our work program is learning about new normal health protocols and introducing the business world to improve the economy during the pandemic through social media. This learning is expected to be able to educate the public about how to deal with new normal conditions so as not to increase the spread of the people who are infected with the COVID-19 virus. In addition, the introduction of the business world is expected to educate the public to educate the public in maintaining economic balance during the pandemic through minimalist business
\end{abstract}

Keywords: Kuliah Kerja Nyata (KKN), New Normal, Business.

\section{abstrak}

Di Tengah situasi darurat yang harus dialami oleh Indonesia, yaitu masa pandemi yang disebabkan oleh virus COVID-19 menyebabkan perubahan sistem pada pelaksanaan Kuliah Kerja Nyata. Yang sebelumnya Kuliah kerja nyata yang dapat dilaksanakan di berbagai daerah dengan ragam mahasiswa lintas daerah, harus mengalami perubahan yaitu pelaksanaan Kuliah Kerja Nyata sesuai domisili mahasiswa tersebut. Program kerja yang kami lakukan adalah pembelajaraan mengenai protokol kesehatan new normal dan pengenalan dunia bisnis guna meningkatkan ekonomi selama masa pandemi melalui media sosial. Pembelajaran ini diharapkan dapat mengedukasi masyarakat mengenai cara menghadapi kondisi new normal agar tidak menambah angkat tersebar nya masyarakat yang terjangkit virus COVID-19. Selain itu pengenalan dunia bisnis diharapkan dapat mengedukasi masyarakat untuk mengedukasi masyarakat dalam menjaga keseimbangan ekonomi di masa pandemi melalui bisnis yang minimalis.

Kata Kunci: Kuliah Kerja Nyata (KKN), New Normal, Bisnis.

\section{PENDAHULUAN}

Kuliah Kerja Nyata $(\mathrm{KKN})$ merupakan proses pembelajaran bagi mahasiswa S1 Universitas Airlangga. Kegiatan ini merupakan pengembangan dari kegiatan sosial yaitu pengabdian masyarakat. Pengabdian kepada masyarakat sendiri merupakan salah 
satu penerapan dari Tri Dharma Perguruan Tinggi, dimana mahasiswa berkewajiban untuk mengaplikasikan ilmu yang sudah didapat di dunia perkuliahan kepada masyarakat luas. Ilmu yang bermanfaat tentunya bukan hanya ilmu yang disimpan untuk diri sendiri atau sekedar disimpan dalam pikiran kita, melainkan ilmu yang diamalkan sesuai fungsinya dan memberikan manfaat untuk orang banyak. Ilmu yang didapatkan akan menjadi percuma jika tidak dapat memberikan dampak perubahan yang signifikan untuk masyarakat. Dalam Undang-Undang pendidikan tinggi, disebutkan bahwa pengabdian kepada masyarakat adalah kegiatan civitas akademika yang memanfaatkan ilmu pengetahuan dan teknologi untuk memajukan kesejahteraan masyarakat dan mencerdaskan kehidupan bangsa. Mahasiswa kepada masyarakat diharapkan dapat berperan sebagai problem solver, motivator, fasilitator, dan dinamisator dalam proses penyelesaian masalah maupun pengembangan masyarakat.

Indonesia dan banyak negara lain di dunia masih berperang melawan virus COVID19. Virus COVID-19 ini adalah virus severe acute respiratory syndrome coronavirus 2(SARS-CoV-2) yang dapat menyebabkan gangguan sistem pernafasan. Virus ini menyebar melalui droplet penderita COVID-19 yang menempel di berbagai tempat umum dan tidak sengaja disentuh oleh orang yang kondisi tubuhnya sedang tidak sehat atau sistem imun nya lemah. Penyebaran virus ini sangatlah cepat dan mudah hingga memakan banyak korban di dunia. Khususnya di Indonesia, situasi yang mengancam ini menyebabkan pemerintah Indonesia harus melakukan kebijakan lockdown dan PSBB pada beberapa daerah. PSBB adalah pembatasan sosial berskala besar, dimana PSBB dan lockdown ini bertujuan untuk mengurangi angka penyebaran virus COVID-19 dengan memaksa masyarakat bekerja di rumah. Untuk ikut serta dalam membantu pemerintah mengurangi resiko tersebarnya virus COVID-19, Universitas Airlangga memutuskan untuk melaksanakan kegiatan Kuliah Kerja Nyata (KKN) sesuai domisili masing-masing mahasiswa. Kuliah Kerja Nyata ini dapat dilaksanakan dengan terjun langsung ke masyarakat domisili tersebut tapi tetap dengan mengikuti protokol kesehatan yang ada. Dikarenakan mahasiswa pada kelompok kelurahan 145 ini berdomisili di Jakarta dan Jakarta berada pada zona merah yaitu zona yang memiliki kasus penyebaran virus sangat tinggi, menyebabkan kelompok kami memiliki keterbatasan pelaksanaan di lapangan. Sehingga kelompok kami memutuskan untuk melakukan pengabdian masyarakat dengan program kerja kami yaitu mengedukasi masyarakat melalui platform media sosial seperti instagram, twitter, youtube, dll.

Kebijakan pemerintah untuk melakukan PSBB dan lockdown berdampak banyak pada kehidupan masyarakat, salah satunya adalah banyak perusahaan yang mengalami defisit dalam perusahaannya dan memutuskan untuk memberhentikan secara paksa pekerja nya untuk menekan angka pengeluaran usaha tersebut. Pemutusan Hubungan kerja (PHK) yang dialami oleh banyak pekerja Indonesia menyebabkan banyak keluarga yang mengalami ketidakseimbangan ekonomi. Untuk menyikapi keadaan masyarakat tersebut maka kami mengadakan program edukasi mengenai dunia bisnis yang dapat dilakukan di rumah. Dunia bisnis untuk beberapa masyarakat masih dianggap hal yang sulit dilakukan karena membutuhkan biaya besar sebagai modal. Banyak juga masyarakat yang malas membangun bisnis dikarenakan tidak memiliki ide dan malas berurusan dalam membuat izin membangun usaha. Pada pengenalan dunia bisnis yang kami programkan diharapkan dapat memberikan ilmu dan tips yang mudah 
bagi masyarakat yang minim pengetahuan dengan dunia bisnis dan kemudian diterapkan pada masyarakat yang ingin menambah penghasilan guna menjaga kestabilan ekonomi.

Keadaan ekonomi negara yang terus menurun menyebabkan pemerintah di Indonesia memutuskan untuk memberhentikan PSBB dan mulai menerapkan kehidupan new normal. Menurut Achmad Yurianto, juru bicara pemerintah Indonesia yang menangani virus COVID-19 mengatakan, masyarakat harus menjaga produktivitas di tengah pandemi virus COVID-19 dengan tatanan baru yang disebut new normal. New normal adalah tatanan baru untuk beradaptasi dengan COVID-19, dimana masyarakat diberi kebebasan untuk melakukan aktivitas kembali di lapangan kerja dengan persyaratan tetap mengikuti protokol kesehatan new normal. Namun minim nya pengetahuan masyarakat mengenai cara menyikapi new normal menyebabkan tingkat penyebaran virus COVID-19 setelah new normal melonjak drastis. Sehingga pada program kerja kedua kelompok kelurahan 145 ini untuk mengedukasi masyarakat mengenai protokol kesehatan new normal yang dipaparkan di youtube dan di sebarkan ke seluruh platform media sosial.

\section{METODE PENGABDIAN MASYARAKAT}

Pada kegiatan Kuliah Kerja Nyata (KKN) BBM ke-62 yang diselenggarakan pada masa pandemi COVID-19 di Indonesia dilaksanakan pada domisili Jakarta. Lokasi kegiatan KKN dilaksanakan di Kelurahan Kalibata, Kecamatan Pancoran, Jakarta Selatan. Sasaran dari kegiatan ini adalah masyarakat semua umur. Program kerja dari kegiatan KKN ini adalah untuk mengedukasi masyarakat dalam menghadapi new normal dan memberikan tips membangun bisnis dengan modal minimalis yang dapat disesuaikan dengan bakat dan minat masyarakat tersebut. Edukasi baik protokol kesehatan new normal dan tips membangun bisnis dengan mudah dikemas dalam bentuk video animasi yang diunggah melalui media youtube.

Persiapan membuat video pertama mengenai new normal ini diawali dengan mencari sumber informasi yang akurat tentang bagaimana protokol kesehatan yang tepat di kondisi tersebut. Sedangkan persiapan membuat video kedua mengenai tips berbisnis diawali dengan mencari informasi mengenai cara berbisnis yang mudah dan contoh bisnis yang sedang laku dipasaran. Informasi yang didapat kemudian dipilih dan dikemas semenarik mungkin dengan pemilihan bahasa yang tepat agar mudah dipahami oleh masyarakat semua umur. Setelah pemilihan bahasa dan penyusunan narasi, video dibuat sesuai dengan alur narasi yang sudah dibuat dan ditambahkan animasi agar lebih menarik. Setelah video selesai dibuat, video tersebut diunggah pada platform youtube dan disebarkan tautannya melalui instagram, whatsapp, twitter, facebook, dan lain-lain kepada masyarakat sekitar. Untuk penyebaran pada daerah terlaksana nya KKN di kecamatan pancoran, tautan tersebut disebarkan melalui grup whatsapp RT/RW setempat. Segala bentuk cara penyampaian ini kami laksanakan dengan memperhatikan protokol kesehatan.

\section{HASIL DAN PEMBAHASAN}

Seperti yang sudah diketahui bahwa virus Covid-19 sendiri dapat menyebar melalui droplet yang keluar ketika seseorang batuk atau bersin (Susilo et al., 2020). Maka dari itu, dalam melaksanakan program edukasi demi mencegah dan mengurangi tingkat 
penularan virus corona, kami menyajikan materi sesuai dengan protokol Kesehatan yang dikeluarkan oleh pemerintah dalam Keputusan Menteri Kesehatan Republik Indonesia Nomor Hk.01.07/Menkes/328/2020. Kami melihat bahwa dari sejumlah poin yang tertera pada protokol tersebut, terdapat beberapa poin sederhana namun penting untuk diketahui, dimengerti, dan diaplikasikan oleh masyarakat seperti (Kementrian Kesehatan Republik Indonesia, 2020) : 1. Mencuci tangan dengan baik dan bena, 2 . Menghindari penggunaan alat pribadi (alat makan, alat solat, dll), 3. Menjaga kebersihan diri dan lingkungan

Tiga tersebut merupakan komponen yang kami tekankan dalam materi edukasi yang kami buat dalam bentuk video ilustrasi rutinitas ketika new normal. Dalam menjelaskan bagaimana cara mencuci tangan yang baik, kami merujuk pada panduan yang diberikan oleh WHO. Ketika mencuci tangan individu disarankan untuk menggunakan sabun dan air yang mengalir, terutama untuk pencegahan Covid-19. Dengan mencuci tangan dengan baik dan efektif, maka segala virus yang mungkin menempel di tangan akan hilang dan mengurangi kemungkinan seseorang terpapar oleh virus Covid-19. Tahapan - tahapan mencuci tangan tersebut yaitu (WHO, 2009) : 1. Membasahi tangan dengan air, 2. Menggunakan sabun, 3. Mengusap kedua telapak tangan bagian dalam, 4. Tangan kanan mengusap punggung dan sela jari tangan kiri, 5. Tangan kiri mengusap punggung dan sela jari kanan, 6. Mengusap sela jari dengan telapak tangan berhadapan, 7 . Membersihkan punggung jari kedua tangan dengan telapak saling mengunci, 8. Membersihkan ibu jari kedua tangan, 9. Memutar ujung jari pada telapak tangan, 10. Bilas hingga bersih dan keringkan

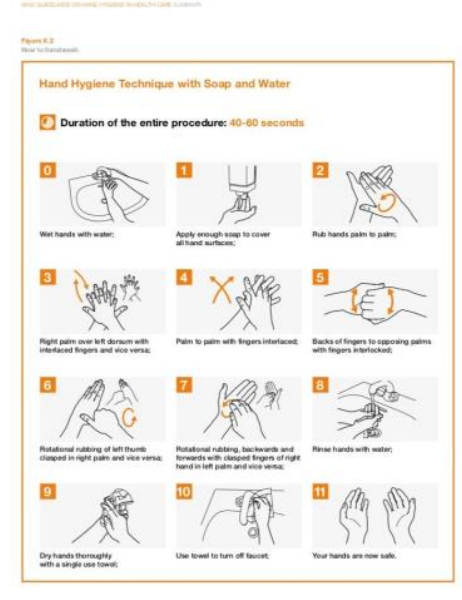

\section{Gambar 1 Panduan cara mencuci tangan dari WHO}

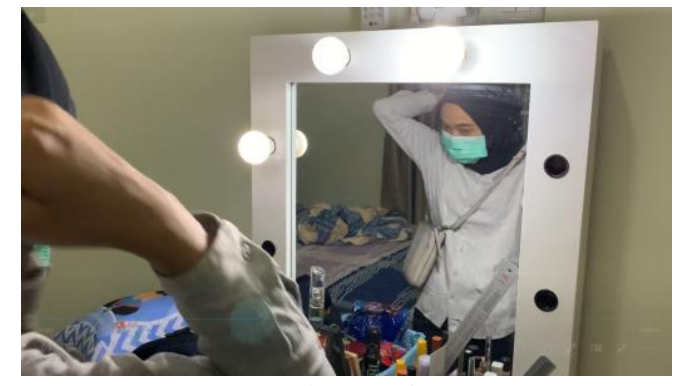

Gambar 2 Clip Video Everyday Life Routine edisi New Normal 
Kemudian pada program kerja yang berkaitan dengan bidang bisnis, mengingat dengan penurunan ekonomi yang dialami oleh banyak pihak akibat pandemi ini. Kami memberikan tips untuk bagaimana caranya membangun sebuah bisnis bagi masyarakat yang ingin memulai namun masih belum tahu cara untuk memulai bisnis tersebut. Banyak dari kegiatan ekonomi mulai dari hal kecil sampai hal besar yang dapat dilakukan di masa pandemi ini contohnya adalah memulai bisnis makanan ringan yang dapat dibeli oleh masyarakat sekitar atau dari kalangan sang penjual. Dapat juga dengan mengunggah makanan yang dijualnya melalui akun Instagram karena di masa pandemi ini media sosial adalah hal yang cukup berpengaruh besar dalam mengisi kekosongan sehari-hari. Dengan bisnis kecil ini semua dapat mendapatkan pemasukan dalam jumlah yang sesuai dengan apa yang dijualnya. Terdapat tiga poin sederhana yang kami sampaikan berkaitan dengan membangun bisnis, dimana poin - poin tersebut akan lebih mudah dimengerti oleh masyarakat awam. Tiga poin yang kami sampaikan dalam video edukasi kami yaitu :

1. Mencari bidang bisnis yang sesuai dengan bakat dan minat

Dalam menjalani sebuah bisnis, tentu perlu untuk terus memiliki ketekunan dalam menjalaninya. Jika individu sudah memiliki bakat serta minat terhadap suatu hal maka akan lebih mudah dalam menjalani kegiatan bisnis barunya. Kemudian setelah mengetahui bakat dan minat, individu dapat mencari target pasar yang seperti apa untuk menjual produk.

\section{Menyiapkan modal}

Modal yang dimaksudkan oleh kami disini tidak hanya berkaitan dengan uang saja, tapi juga waktu, pikiran, dan tenaga. Hal ini dikarenakan dalam membangun bisnis, individu juga harus memiliki perencanaan yang jelas mengenai bisnis yang akan dijalankan. individu juga harus memastikan bahwa modal yang direncanakan sesuai dengan kapabilitas dirinya.

\section{Promosi bisnis}

Setelah menyiapkan modal, memiliki perencanaan bisnis, dan sudah mulai menjalankan bisnis, individu dapat segera mempromosikan usaha bisnisnya. Target promosi bisnis terdekat oleh individu yaitu sanak saudara, teman dekat, tetangga lingkungan rumah, dan lain - lainnya. Namun, karena adanya Covid-19, maka individu dianjurkan untuk melakukan bisnis online dimana individu tidak harus beranjak dari rumahnya.

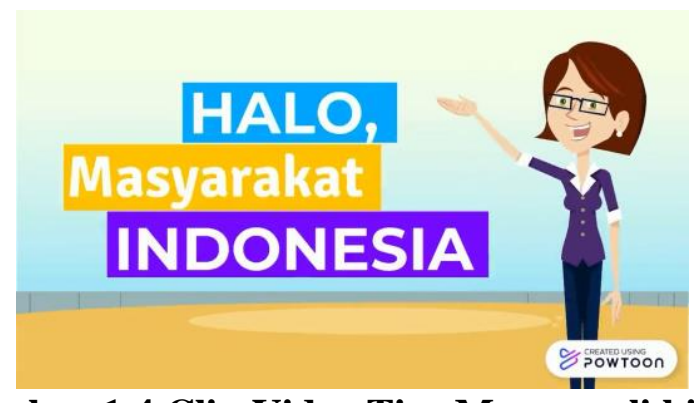

Gambar 1.4 Clip Video Tips Mengawali bisnis 


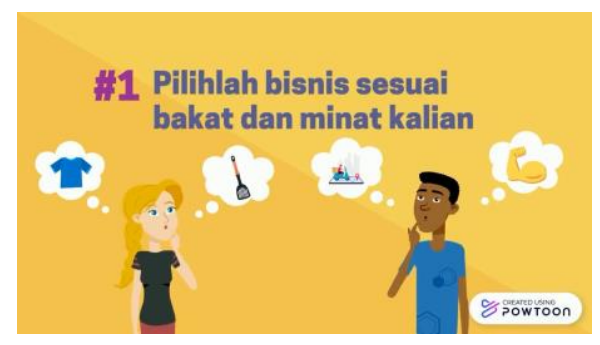

\section{Gambar 1.5 Clip Video Tips Mengawali Bisnis}

\section{PENUTUP}

\section{Simpulan}

Setelah dilaksanakannya program kerja KKN dari kelompok 145 yaitu dengan memberikan informasi mengenai kehidupan New Normal dan tips berbisnis yang mudah kepada masyarakat sekitar kecamatan pancoran melalui situs youtube. Dari program tersebut didapat hasil masyarakat yang mulai paham akan protokol kesehatan di daerah pancoran dan sekitaran Jakarta lainnya dan juga ada beberapa pemuda yang mulai mencoba berbisnis di rumah masing-masing. Sehingga dapat disimpulkan, cara mengedukasi masyarakat melalui media sosial terbilang efisien dan manfaatnya tetap bisa dirasakan oleh masyarakat luas.

\section{Saran}

Dengan berakhirnya program Kuliah Kerja Nyata yang dilaksanakan di RT 01 Kelurahan Kalibata Kecamatan Pancoran, Jakarta. Masyarakat baik yang berada di lokasi KKN kami maupun masyarakat luas yang melihat hasil dari program kerja kami diharapkan untuk selalu dapat meningkatkan ketertiban dalam menaati protokol kesehatan. kemudian, semoga masyarakat dapat tetap berdaya dan berkembang di tengah pandemi Covid-19 ini.

\section{DAFTAR PUSTAKA}

Ali, Wangdra. 2010. Technopreneurship dalam Perspektif Bisnis Online. Badoose Media. Jakarta.

Ariansyah A. ketika semua Harus Memulai Fase "New Normal” Hadapi COVID-19 [Internet]. [dikutip 13 Juli 2020,13.30]. https://bnpb.go.id/berita/ketika-semuaharus-memulai-fase-new-normal-hadapi-covid19-1

Hamborsky J, Kroger A, Wolfe C. 2015. National Center for Immunization and Respiratory Diseases (U.S.), Communication and Education Branch. Epidemiology and prevention of vaccine-preventable disease. United State.

Kementerian Kesehatan Republik Indonesia. (2020). Keputusan Menteri Kesehatan Republik Indonesia Tentang Panduan Pencegahan dan Pengendalian COVID19. 2019. https://covid19.go.id/storage/app/media/Regulasi/KMK No. 
HK.01.07-MENKES-413-2020 ttg Pedoman Pencegahan dan Pengendalian COVID-19.pdf

Pereault, Charty. 2008. Pemasaran Dasar. Salemba Empat. Jakarta

Prasetijo, Ihalauw. 2004. Perilaku Konsumen. Penerbit Andi. Yogyakarta

Susilo, A., Rumende, C. M., Pitoyo, C. W., Santoso, W. D., Yulianti, M., Heri Kurniawan, H., Sinto, R., Singh, G., Nainggolan, L., Nelwan, E. J., Chen, L. K., Widhani, A., Wijaya, E., Wicaksana, B., Maksum, M., Annisa, F., Jasirwan, C. O. M., \& Yunihastuti, E. (2020). Coronavirus Disease 2019: Tinjauan Literatur Terkini. Jurnal Penyakit Dalam Indonesia, 7(1), 45. https://doi.org/10.7454/jpdi.v7i1.415

WHO. (2009). on Hand Hygiene in Health Care First Global Patient Safe 